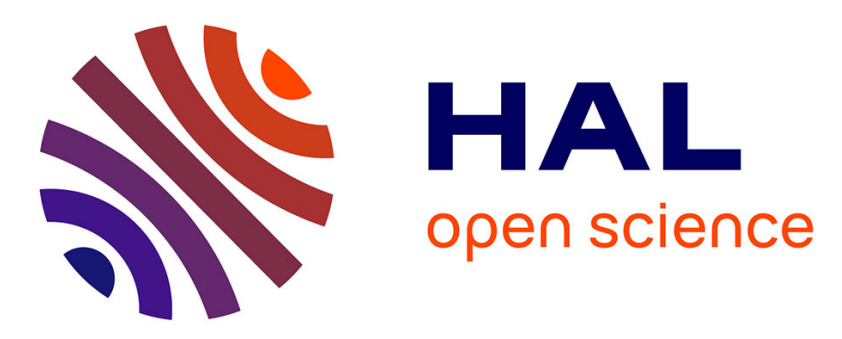

\title{
A snapshot of soil water composition as an indicator of contrasted redox environments in a hedged farmland plot
}

Patrick Albéric, Aurélie Vennink, Sophie Cornu, Hocine Bourennane, Ary

Bruand

\section{To cite this version:}

Patrick Albéric, Aurélie Vennink, Sophie Cornu, Hocine Bourennane, Ary Bruand. A snapshot of soil water composition as an indicator of contrasted redox environments in a hedged farmland plot. Science of the Total Environment, 2009, 407 (21), pp.5719-5725. 10.1016/j.scitotenv.2009.07.005 . insu-00413682

\section{HAL Id: insu-00413682 \\ https://hal-insu.archives-ouvertes.fr/insu-00413682}

Submitted on 7 Sep 2009

HAL is a multi-disciplinary open access archive for the deposit and dissemination of scientific research documents, whether they are published or not. The documents may come from teaching and research institutions in France or abroad, or from public or private research centers.
L'archive ouverte pluridisciplinaire HAL, est destinée au dépôt et à la diffusion de documents scientifiques de niveau recherche, publiés ou non, émanant des établissements d'enseignement et de recherche français ou étrangers, des laboratoires publics ou privés. 


\title{
A snapshot of soil water composition as an indicator of contrasted redox environments in a hedged farmland plot
}

\author{
Patrick Albéric a Aurélie Vennink ${ }^{a}$, Sophie Cornu ${ }^{b}$, Hocine Bourennane ${ }^{c}$ and Ary \\ Bruand $^{\mathrm{a}}$
}

${ }^{a}$ Université d'Orléans, CNRS/INSU, Institut des Sciences de la Terre d'Orléans (ISTO), 1A Rue de la Férollerie, 45071 Orléans Cedex 2, France

${ }^{b}$ INRA Aix en Provence, Unité de Géochimie des Sols et des Eaux, Europôle de l'Arbois, 13545 Aix-en-Provence Cedex 4, France

${ }^{\mathrm{c} I N R A}$ Orléans, Unité de Science du Sol, Avenue de la Pomme de Pin, BP 20619, 45166 Olivet Cedex, France

\begin{abstract}
While soil water composition has long been recognised as being related to soil type (characteristics of the horizons), the influence of structures resulting from agricultural activities (hedges, ditches, wheel ruts, etc) is still under discussion. This work was undertaken to show that a snapshot of spatial variability of the geochemical characteristics of soil water at the scale of a plot can improve our understanding of soil geochemistry in a farmland setting. We selected a 3 hectare hedged plot located on a hillside, limited by a stream and used as pasture where soils have developed in weathered gneiss. The water depth, electrical conductivity, major ions, temperature, $\mathrm{pH}$, dissolved organic carbon (DOC) content, dissolved oxygen content, fluorescence, alkalinity, $\mathrm{Fe}^{2+}, \mathrm{Mn}^{2+}, \mathrm{NO}_{2}{ }^{-}, \mathrm{Fe}(\mathrm{III})$ and $\mathrm{F}^{-}$contents were measured in 62 auger holes randomly drilled on the site. Four sectors were identified in order to describe the distribution of the main geochemical parameters. Electrical conductivity and some major ions, especially sulphate, had larger concentrations near hedges where oxic conditions prevailed. These features were attributed to the impact of the linear anthropogenic network on the circulation of subsurface soil waters and evapo-transpiration and represent sector I. Dissolved Mn was an indicator of well channelled runoff subsurfaces facilitating the circulation of more highly reducing water (sector III), while DOC probably marked areas drained less well, with a prolonged contact time between soil solutions and organic topsoil horizons (sector II). The presence of dissolved $\mathrm{Mn}$ and Fe(II) indicates bottomland anoxic conditions (sector IV). It is concluded that a survey of the chemical composition of soil water may be a direct approach to show the influence of permanent structures on current soil properties and dynamics.
\end{abstract}

Keywords: Oxic; Anoxic; Soil water solutes; Planosol; Manganese; Dissolved organic matter

\section{Introduction}

Formation of soils results from the cumulative effect over time of chemical fluxes responsible for lateral and vertical differentiations. Numerous studies have addressed the spatial variability of chemicals in solid phases of soil resulting from these fluxes ([Arrouays et al., 2000], [Bourennane et al., 2003] and [McBratney et al., 2003]). In order to discuss the present geochemical dynamics of soils and possible transport of pollutants, however, solute transport must be considered in soils that in most cases are now affected by agricultural practices with their consequences at different scales (Bruand, 2005). Current geochemical dynamics of soils 
can be discussed using soil water contributions to streamflows. This enables the analysis of the spatial and temporal variability of chemical processes in soils according to the size of the catchment contributing to streamflows ([Avila et al., 1995] and [Curmi et al., 1997]). The seasonal variability of chemical interactions between solutes and solid phases in soils may also be surveyed over time by sampling soil water at different locations ([Gasser et al., 1994], [Biddle et al., 1995], [Bourrié et al., 1999] and [Lilienfein et al., 2000]). On the other hand, with the exception of a study by Manderscheid and Matzner (1995) averaging annual fluxes through soils, there are a few studies on the spatial variation of soil solution chemistry at the catchment scale, especially at the plot scale which is the basic land unit in terms of agricultural activities.

At the plot scale, the composition and circulation of water are related to the $3 \mathrm{D}$ distribution of horizons and their respective characteristics, but also to anthropogenic structures such as hedges, ditches or wheel ruts if present. Water circulation and especially lateral underflow above clayey horizons when present, can induce specific chemical transfers and reactions, especially in hydromorphic soils (Bourrié et al., 1994). The aim of this work was to show that a snapshot of the spatial variability of geochemical characteristics of soil water can improve our understanding of soil dynamics in land plots with non-uniform areas such as those encountered in landscapes marked by hedgerows.

\section{Materials and methods}

The site is located on the Aigurande plateau in the French Massif Central, $10 \mathrm{~km}$ south of La Châtre (Indre) and was intensively surveyed by Salvador-Blanes (2002) in order to analyse the spatial distribution of major and trace elements in soil minerals along a toposequence. The approximated 3 hectare (ha) plot Le Pré Neuf is located on a hillside, used as pasture. Soils are Planosols (ISSS Working Group RB, 1998) developed on gneissic alterites and exhibit a stony horizon rich in Fe-Mn oxides overlaying a clayey B horizon (below $50 \mathrm{~cm}$ ). Upper horizons are allochthonous and derived from colluvial materials of amphibolitic and gneissic origin. Colluvial materials differentiate into three horizons: a sandy-loam to clay-loam organic-rich A-horizon ( 25 to $30 \mathrm{~cm}$ thick) and two E horizons, one of them rich in concretions and gravels (Cornu et al., 2005). A seasonal water table is found within the surface horizons located above the B-horizon from December to May. The soil was drilled with a manual auger to the top of the B-horizon in 62 georeferenced points located on two grids $\left(25 \times 25\right.$ and $40 \times 40 \mathrm{~m}$ cells) with about one sample per $300 \mathrm{~m}^{2}$ (Fig. 1). The sampling campaign lasted for 3 consecutive days in winter. Sampling, field and laboratory analysis methods are detailed in the Supplementary file caption.

\section{Results and discussion}

\subsection{Sampling quality and chemical consistency}

Even in the lower part of Le Pré Neuf (Fig. 1), where soil waterlogging was maximized, water in the auger holes rose slowly, seeping both laterally and from the soil bottom layer with high permeability. Mixing with water from small superficial puddles responsible for the soggy ground aspect of the plot was negligible. Moreover, quasi-anoxia and a high $\mathrm{Fe}^{2+}$ content of some samples indicated no mixing with superficial waters during sampling; this will be discussed in more detail below. Solutions sampled may be regarded as free-flowing soil waters as stated by Avila et al. (1995). The chemical composition of the soil water was 
consistent with ionic balance ( $<5 \%$ for most samples), electrical conductivity and bulk basic redox rules.

Descriptive statistics and variography analysis were performed on the complete data set (Supplementary file), but since the gain for geochemical understanding of the soil water was small and a detailed account would exceed the scope of this study, the presentation of the results and their discussion focus on maps established for selected key parameters (Fig. 2). We plotted raw data with dot sizes proportional to analytical values rather than maps resulting from kriging since the experimental variograms of the data and their theoretical fitted models in some cases were too disparate for the required characteristics in order to accurately estimate spatial variability. Nevertheless, close relations between specific parameters were evident, for instance (i) electrical conductivity (Fig. 2a) displayed common patterns to ionic strength (Fig. 2b) and major ions, e.g. sulphate (Fig. 2e), (ii) dissolved oxygen-rich samples were also rich in nitrates (Fig. $2 \mathrm{f}$ and g), (iii) samples containing nitrites (Fig. $2 \mathrm{~h}$ ) had smaller oxygen and larger $\mathrm{Mn}^{2+}$ contents (Fig. 2l) than other samples, (iv) the sample richer in $\mathrm{Fe}^{2+}$ was quasi-anoxic (Fig. 2k), and (v) samples with higher dissolve organic carbon (DOC) gave higher fluorescence intensity (Fig. $2 \mathrm{i}$ and $\mathrm{m}$ ) and contained low nitrate and dissolved oxygen contents, consistent with DOC accumulation in rather poor oxic conditions.

Several samples appeared to differ significantly from the surrounding samples: (i) W15 next to the hedge and south of the path (Fig. 1) showed high major ion concentrations, conductivity, $\mathrm{pH}$ and alkalinity (Fig. $2 \mathrm{j}$ and $\mathrm{n}$ ), (ii) W4 and more clearly J5 at the slope bottom were the only $\mathrm{Fe}^{2+}$ rich samples $\left(2.6 \mathrm{mg} \mathrm{L}^{-1}\right.$ in J5) which were the least oxygenated, (iii) $\mathrm{J} 5$ was enriched in $\mathrm{Si}, \mathrm{Al}$ and $\mathrm{Fe}$ (III) $\left(13.4,4.6\right.$ and $11.7 \mathrm{mg} \mathrm{L}^{-1}$ respectively) compared to average values recorded (less than $9.1,1.1$ and $1.0 \mathrm{mg} \mathrm{L}^{-1}$, respectively). Site J33, next to the hedge north of the path, was a muddy hole with little free water rich in $\mathrm{Si}, \mathrm{Al}$ and $\mathrm{Fe}(\mathrm{III})$ (14.8, 5.5 and $3.9 \mathrm{mg} \mathrm{L}^{-1}$ respectively), probably due to the presence of colloids.

\subsection{Identification of sectors with similar soil water characteristics}

Observing the distribution of soil water solutes in the plots enabled separate sectors to be identified (Fig. 3).

One sector (sector I) was located close to the west and north hedges of the plot Le Pré Neuf. It was characterised by higher concentrations of all major ions (and hence greater electrical conductivity) and dissolved oxygen. Water table depth in the auger holes in this sector was relatively deep (Fig. 2c) and water temperature (Fig. 2d) was relatively warm, less affected by cold winter air. A deeper water table and higher major solute concentrations may be related to the influence of hedges on soil water movement. A high rate of soil drying due to the evaporative capacity of trees has previously been observed, induced by hedges in "bocages" (Caubel et al., 2003). Greater ionic strengths in this part of the plot probably resulted from the cumulative effect of soil drying cycles in the summer and the lack of dilution by upstream water because of the presence of the footpath. Indeed, water movement influenced by hedges and slope can better explain the depth of the perched water table in this sector than the effect of trees and bushes at this time of the year (February). On the other side of the path (north side) all soil solutions sampled were diluted regardless of water depth in the auger holes. Although the area selected for solution sampling was limited to the recognised zone with Planosols, the hypothesis of spatial continuity of water flow and consequently of solute transport along the slope underneath the path from the plot Les Grands Chaumes to the plot 
Le Pré Neuf was not supported by the data recorded. The discussion below thus focuses only on Le Pré Neuf.

The second sector (sector II) corresponds to soil water with large DOC (Fig. 3). Factors controlling DOC in soils are complex, with the two main sources being litter and humus (Kalbitz et al., 2000). According to these authors, the release of DOC can be influenced by numerous factors such as substrate quality, e.g. $\mathrm{C} / \mathrm{N}$ ratio, decomposer community, adsorption in mineral soil horizons, $\mathrm{pH}$, ionic strength, temperature, soil moisture, water fluxes and redox conditions (Fiedler and Kalbitz, 2003). Many of these factors affect DOC in different ways making their effects difficult to estimate. Moreover, field and laboratory studies often lead to contradictory results. The control of DOC dynamics by these factors has been considered at the overall and local scales by comparing different situations. At the sub-plot scale, the variation of some of these factors can be more limited or better constrained. In the plot studied, used as pasture, litter originates from the grass cover. The spatial distribution of humus content in the topsoil should have been a significant parameter controlling DOC but was not documented. Higher ionic strengths (enhancing coagulation), more oxic conditions (leading to more Fe-Mn oxides in the subsoil) and a deeper water table depth in sector I may explain a greater adsorption of DOC on mineral surfaces than in sector II. Anaerobic conditions (as in sector IV, see below) do not appear to lead to greater DOC since clay minerals in these Gleysols at the bottom of the plot may enhance retention (Fiedler and Kalbitz, 2003). Beside soil solution chemistry, water flux and contact time are key controlling factors (Kalbitz et al., 2000). Since DOC is spatially correlated with shallow water levels measured in the auger holes, contact time between the soil solution and the humic topsoil horizons is probably one of the major factors controlling DOC in this plot. Fluorescence intensity was measured to confirm DOC data and to look for variations of fluorescence vs. DOC ratio. The spatial distribution of both parameters almost overlaps, thus increasing the significance of sector II individualisation. Moreover, this overlap suggests that an almost unique DOC source predominates, unlike what is observed in aquatic systems (Zumstein and Buffle, 1989). Detailed fluorescence spectroscopy studies of humic substances (Milori et al., 2002), however, can distinguish various degrees of humification and possibly biodegradability ([Marschner, 2003] and [Marchand et al., 2006]).

The third separate geochemical sector (sector III) is an elongated strip with higher $\mathrm{Mn}^{2+}$ and fluoride concentrations (Fig. 21 and p). This sector crosses a patch of poorly oxygenated water from south to north, then a zone with moderately oxygenated waters in the direction to the hedges. The role of this sector will be discussed below.

Finally, two points (J5 and W4) are typical of a reduced environment. Very small (almost zero) oxygen and nitrate concentrations and high dissolved $\mathrm{Fe}^{2+}$ (Fig. 2k) and $\mathrm{Mn}^{2+}$ characterise sector IV (Fig. 3). This bottomland sector lies at the edge of the Planosol extension in Le Grand Pré, the soils considered then being Gleysols since they are very close to the banks of the stream. In this sector, vertical water flow between the top horizon and the underlying alterite would not be restricted because of the lack of a clayey B-horizon. The presence of soil water with a high $\mathrm{Fe}(\mathrm{II})$ content has previously been recognised in similar locations in the landscape ([Bourrié et al., 1994], [Curmi et al., 1997] and [Chaplot et al., 2000]).

The conclusion at this point is that the spatial variability of soil water solutes at the plot scale in this edged farmland with Planosols must be considered as being spatially structured into several sectors. Spatial organisation is structured according to determinant factors, among 
which (i) the highly reducing conditions of the bottomland, (ii) the linear anthropic network, especially hedges, (iii) and particular linear structures not directly linked to the surface slope or the surface drainage network.

\subsection{Mn and Fe mobility}

When examining the $\mathrm{Mn}^{2+}$ content in sectors III and IV, two contrasting situations can be described:

(i) In the bottomland area (sector IV), high dissolved Mn concentrations corresponded to real anoxic conditions with no $\mathrm{Mn}$ oxides in the soil and high dissolved $\mathrm{Fe}^{2+}$ concentrations in soil water. The calculation of saturation indices for common manganese oxide minerals (birnessite, pyrolusite, manganite, hausmannite) showed a large undersaturation. The aim of this saturation index calculation was not to study solution equilibrium with respect to $\mathrm{Mn}$ oxides actually present in the soil since most $\mathrm{Mn}$ has been previously shown to be associated with Fe oxides (Cornu et al. 2005); rather, is was calculated to compare the two distinct sectors III and IV according to their saturation status versus any arbitrary Mn oxide. Redox potentials were not obtained from field Pt-electrode measurements but were deduced from $\mathrm{Fe}(\mathrm{III}) / \mathrm{Fe}(\mathrm{II})$ ratios which provide overestimated values due to the presence of $\mathrm{Fe}(\mathrm{III})$ colloids. Moreover, redox potentials are known to be controlled in similar environments primarily by $\mathrm{Fe}(\mathrm{II}) / \mathrm{Fe}(\mathrm{III})$ hydroxides ([Bourrié et al., 1999] and [Feder et al., 2005]). Thus, as stated above, saturation indices were calculated only for relative comparisons of sectors.

(ii) Dissolved manganese and moderate oxygen levels coexisted along the central north-south axis (sector III), leading to oversaturated conditions, in agreement with the presence of a horizon rich in Fe-Mn concretions above the clayey B-horizon of the Planosol (Cornu et al., 2005).

Sector IV appears either as a zone where manganese minerals have been dissolved or as a zone where underflowing dissolved Mn would not precipitate. On the contrary, sector III is a zone where dissolved Mn ultimately precipitates, either because redox conditions have turned quite rapidly from anoxic to oxic, or because Mn-rich anoxic soil waters have invaded subsurface channels and have mixed with more highly oxygenated waters. The latter explanation leads to the hypothesis of a lateral supply of water rich in $\mathrm{Mn}^{2+}$ straight along sector III. Going further in that direction would require the study of subsurface flows on top of the B horizon. The surface area drained at any given point of the plot was calculated from the digital terrain model (DTM) on top of the B horizon. This process showed a subsurface runoff network connected downward to the stream channel which was not detectable from the floor surface, especially along two north-south drainage axes, where the main axis was exactly superimposed on Mn sector III, the other branching off northerly from sector IV (W4 spot Fig. 3). The origin of the anoxic waters remains unknown since an area with anoxic soil water was not identified upland to the plots, with the only anoxic sector being located downland. Alternatively, anoxic water confined under the B-horizon could flow upward where it is thin or absent. Such a situation exists both at the top and the bottom of the plot and required detailed study. The presence of a higher fluoride concentration in sector III (Fig. 2p) could indicate a contribution of waters originating from a metamorphic rock aquifer (Banks et al., 1998).

Regardless of the relationships between soil water and that located in underlying alterites that would demand further development, this snapshot of the spatial distribution of dissolved Mn 
in the plot provides insight into the role of fast and slow subsurface lateral water flows on the behaviour of metals in soils. Lateral subsurface water flow can be quite fast and can inhibit the precipitation of metal oxides along channels at the top surface of the B-horizon, when it causes slow changes of soil solutions as well as metal oxide precipitation in the area of least drainage such as the central inter-channel sector II. Thus, lateral flooding from the northsouth axis could periodically supply lower permeability soil areas with dissolved metals and enhance metal oxide concretion in the mineral subsoil horizons. The presence of spatial structures organising subsurface water flow could not be predicted from the main slope. The detailed mapping of these structures at the plot scale should lead to a better understanding of the determining factors controlling dissolved organic matter and metal dynamics.

\section{Conclusion}

The objective of our work was to obtain a detailed picture of the spatial distribution of solutes in soil water at the plot scale in hedged farmland. Our results showed that several sectors can be defined. They were distributed according to: (i) the location of evaporative processes along hedgerows, (ii) the anoxic characteristics of the bottomland, (iii) the enhanced circulation of reduced metals such as Mn through subsurface runoff channels, and subsequently (iv) the areas of lower permeability lying between the drainage axes. The snapshot of solute distribution that was recorded in this work highlights the significance of lateral transfers due to the role of hedges and paths, and the existence of preferential subsurface runoff channels onto the B-horizon. Documenting the spatial distribution of contrasted redox environments in land plots would enable better predictions of the behaviour of trace metals or organic micropollutants in soils.

\section{Acknowledgements}

The authors thank Patrick Baillif (ISTO), Catherine Pasquier, Pierre Courtemanche and Bernard Renaux (INRA) for ICP analysis, D-GPS setting of the field grids and help in hand auger drilling. This study was financed by Le Conseil Régional du Centre (Regional Council of the Centre Region) as part of the METALOE program. We are also indebted to two anonymous reviewers for their constructive comments and in-depth editing help.

\section{References}

Andersen et al., 2002 M.K. Andersen, M. Raulund-Rasmussen, B.W. Strobel and H.C.B. Hansen, Adsorption of cadmium, copper, nickel, and zinc to a poly(tetrafluorethene) porous soil solution sampler, J Environ Qual 31 (2002), pp. 168-175.

Arrouays et al., 2000 D. Arrouays, S. Martin, A. Lepretre and H. Bourennane, Short-range spatial variability of metal contents in soil on a one hectare agricultural plot, Commun Soil Sci Plant Anal 31 (2000), pp. 387-400.

Avila et al., 1995 A. Avila, D. Bonilla, F. Rodà, J. Piňol and C. Neal, Soilwater chemistry in a holm oak (Quercus ilex) forest: inferences on biogeochemical processes for a montaneMediterranean area, J Hydrol 166 (1995), pp. 15-35

Banks et al., 1998 D Banks, B Frengstad, AK Midtgård, JR Krog and T Strand, The chemistry of Norwegian groundwaters: I. The distribution of radon, major and minor elements in 1604 crystalline bedrock groundwaters, Sci Total Environ 222 (1998), pp. 71-91. 
Biddle et al., 1995 D. Biddle, D.J. Chittleborough and R.W. Fitzpatrick, Field monitoring of solute and colloid mobility in a gneissic sub-catchment, South-Autralia, Appl Clay Sci 9 (1995), pp. 433-442.

Bourennane et al., 2003 H. Bourennane, S. Salvador-Blanes, S. Cornu and D. King, Scale of spatial dependence between chemical properties of topsoil and subsoil over a geologically contrasted area (Massif central, France), Geoderma 112 (2003), pp. 235-251

Bourrié et al., 1994 Bourrié G, Maître V, Curmi P. Mise en évidence de deux dynamiques saisonnières du fer dans les sols hydromorphes en climat tempéré, vol. 318. Compte Rendus de l'Académie des Sciences — Série II 1994;87-92.

Bourrié et al., 1999 G. Bourrié, F. Trolard, J.M.R. Genin, A. Jaffrezic, V. Maitre and M. Abdelmoula, Iron control by equilibria between hydroxyl-Green Rusts and solutions in hydromorphic soils, Geochim Cosmochim Acta 63 (1999), pp. 3417-3427.

Bruand, 2005 A Bruand, Toward conditions favourable to mobility of trace elements in soils, C.R. Geoscience 337 (2005), pp. 549-550.

Caubel et al., 2003 V. Caubel, C. Grimaldi, P. Merot and M. Grimaldi, Influence of a hedge surrounding on seasonal soil-water movement, Hydrol Process 17 (2003), pp. 1811-1821.

Chaplot et al., 2000 Chaplot V, Walter C, Curmi P, Grimaldi C. Morphological features and temporal variations of $\mathrm{Fe}(\mathrm{II})$ presence in Armorican Massif soil covers. Example of two hillslopes developed on granite and schist, vol. 330. Compte Rendus de l'Académie des Sciences — Série II — Earth and Planetary Science 2000;125-32.

Cornu et al., 2005 S. Cornu, V. Deschatrettes, S. Salvador-Blanes, B. Clozel, M. Hardy, S. Branchut and L. Le Forestier, Trace element accumulation in Mn-Fe-oxide nodules of a planosolic horizon, Geoderma 125 (2005), pp. 11-24.

Curmi et al., 1997 P. Curmi, J. Bidois, G. Bourrié, C. Cheverry, P. Durand, C. GascuelOdoux, J.C. Germon, V. Hallaire, C. Hénault, A. Jaffrezic, P. Mérot, F. Trolard, C. Walter and M. Zida, Rôle du sol sur la circulation et la qualité des eaux au sein de paysages présentant un domaine hydromorphe, Etude et Gestion des Sols 4 (1997), pp. 95-114.

Feder et al., 2005 F. Feder, F. Trolard, G. Klingelhöfer and G. Bourrié, In situ Mössbauer spectroscopy: evidence for green rust (fougerite) in a gleysol and its mineralogical transformations with time and depth, Geochim Cosmochim Acta 68 (2005), pp. 4463-4483.

Fiedler and Kalbitz, 2003 S. Fiedler and K. Kalbitz, Concentrations and properties of dissolved organic matter in forest soils as affected by the redox regime, Soil Sci 168 (2003), pp. 793-801.

Gasser et al., 1994 U.G. Gasser, S.J. Juchler and H. Sticher, Chemistry of soil water from serpentinic soils: importance of colloids in the transport of Cr, Fe, Mg and Ni, Soil Sci 158 (1994), pp. 314-322. 
ISSS Working Group RB, 1998 ISSS Working Group RB, World reference base for soil resources: introduction 209. In: J.A. Deckers, F.O. Nachtergaele and O.C. Spaargaren, Editors, International society 210 of soil science (ISSS) (First Ed), ISRIC-FAO-ISSS-Acco. Leuven (1998).

Kalbitz et al., 2000 K. Kalbitz, S. Solinger, J.H. Park, B. Michalzik and E. Matzner, Controls on the dynamic of dissolved organic matter in soils: a review, Soil Sci 165 (2000), pp. 277304.

Katsuyama and Ohte, 2002 M. Katsuyama and N. Ohte, Determining the sources of stormflow from the fluorescence properties of dissolved organic carbon in a forested headwater catchment, J Hydrol 268 (2002), pp. 192-202.

Lilienfein et al., 2000 J. Lilienfein, W. Wilcke, L. Vilela, S. do Carmo Lima, R. Thomas and W. Zech, Effect of no tillage and conventional tillage systems on the chemical composition of soil solid phase and soil solution of Brazilian savanna Oxisols, J Plant Nutr Soil Sci 163 (2000), pp. 411-419.

Maitre et al., 1991 V. Maitre, G. Bourrié and P. Curmi, Contamination of collected soil water samples by the dissolution of the mineral constituents of porous P.T.F.E. cups, Soil Sci 152 (1991), pp. 289-293.

Manderscheid and Matzner, 1995 B. Manderscheid and E. Matzner, Spatial and temporal variation of soil solution chemistry and ion fluxes through the soil in a mature Norway Spruce (Picea abies (L.) Karst.) stand, Biogeochemistry 30 (1995), pp. 99-114.

Marchand et al., 2006 C. Marchand, P. Albéric, E. Lallier-Vergès and F. Baltzer, Distribution and characteristics of dissolved organic matter in mangrove sediment pore waters along the coastline of French Guiana, Biogeochemistry 81 (2006), pp. 59-75.

Marschner, 2003 B. Marschner and K. Kalbitz, Controls of bioavailability and biodegradability of dissolved organic matter in soils, Geoderma 113 (2003), pp. 211-235.

McBratney et al., 2003 A.B. McBratney, M.L. Mendonça Santos and B. Minasny, On digital soil mapping, Geoderma 117 (2003), pp. 3-52.

Milori et al., 2002 D.M.B.P. Milori, L. Martin-Neto, C. Bayer, J. Mielniczuk and V.S. Bagnato, Humification degree of soil humic acids determined by fluorescence spectroscopy, Soil Sci 167 (2002), pp. 739-749.

Mopper and Schultz, 1993 K. Mopper and C.A. Schultz, Fluorescence as a possible tool for studying the nature and water column distribution of DOC components, Mar Chem 41 (1993), pp. 229-238.

Podda and Michard, 1994 F. Podda and G. Michard, Mesure colorimétrique de l'alcalinité, Compte Rendus de l'Académie des Sciences — Série II 319 (1994), pp. 651-657.

Salvador-Blanes, 2002 Salvador-Blanes S. Déterminisme de la distribution spatiale des éléments majeurs et traces dans les sols en contexte métamorphique. $\mathrm{PhD}$ thesis, Université François Rabelais, Tours, 2002. 
Zumstein and Buffle, 1989 J. Zumstein and J. Buffle, Circulation of pedogenic and aquatic organic matter in an eutrophic lake, Wat Res 23 (1989), pp. 229-239. 
Figures

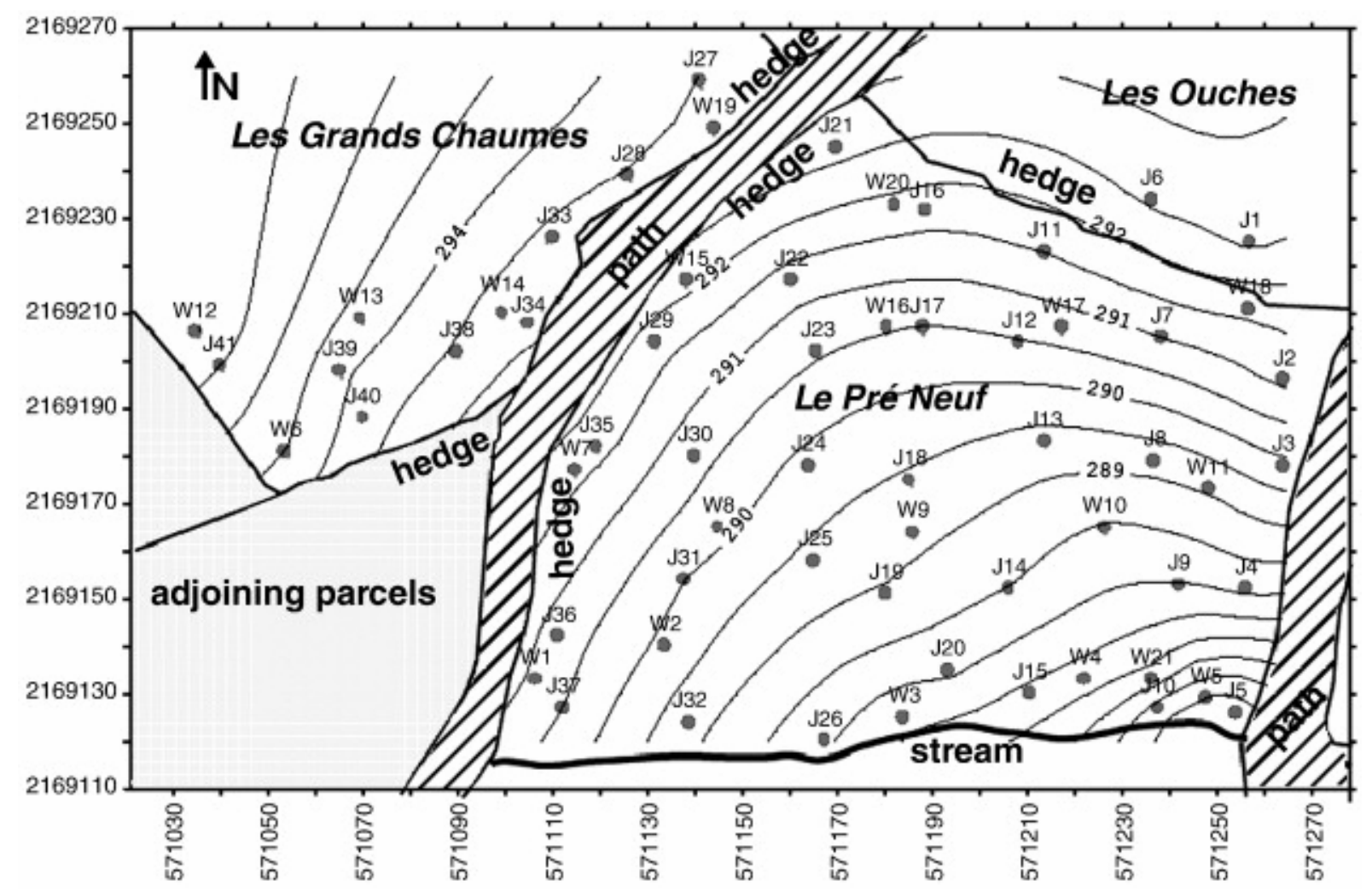

Fig. 1. Site and location of auger holes for water samples. Narrow lines are contour lines from $285 \mathrm{~m}$ (SE) to $296 \mathrm{~m}$ high (NW). Lambert metric coordinates are presented on the abscissa and ordinate. 

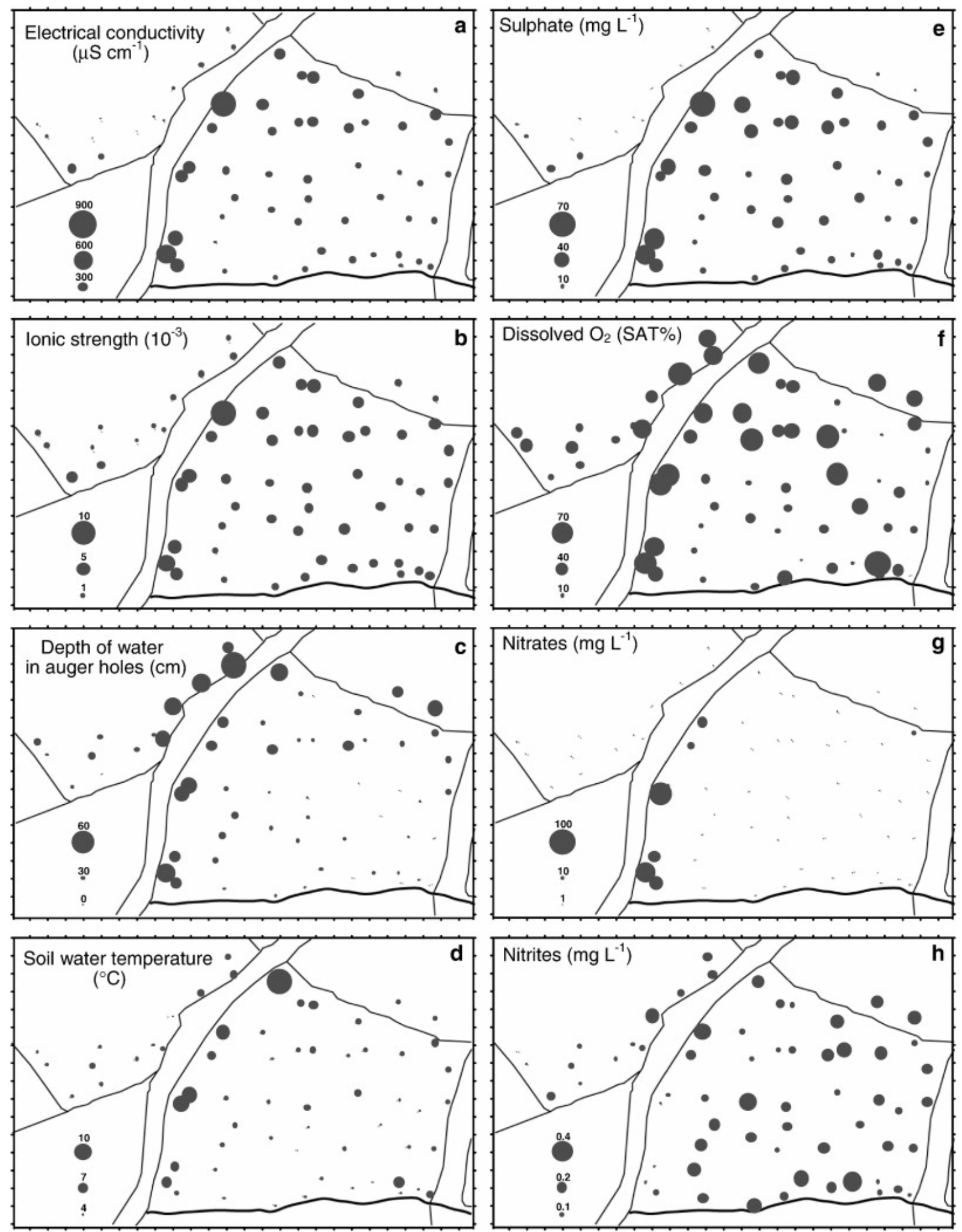

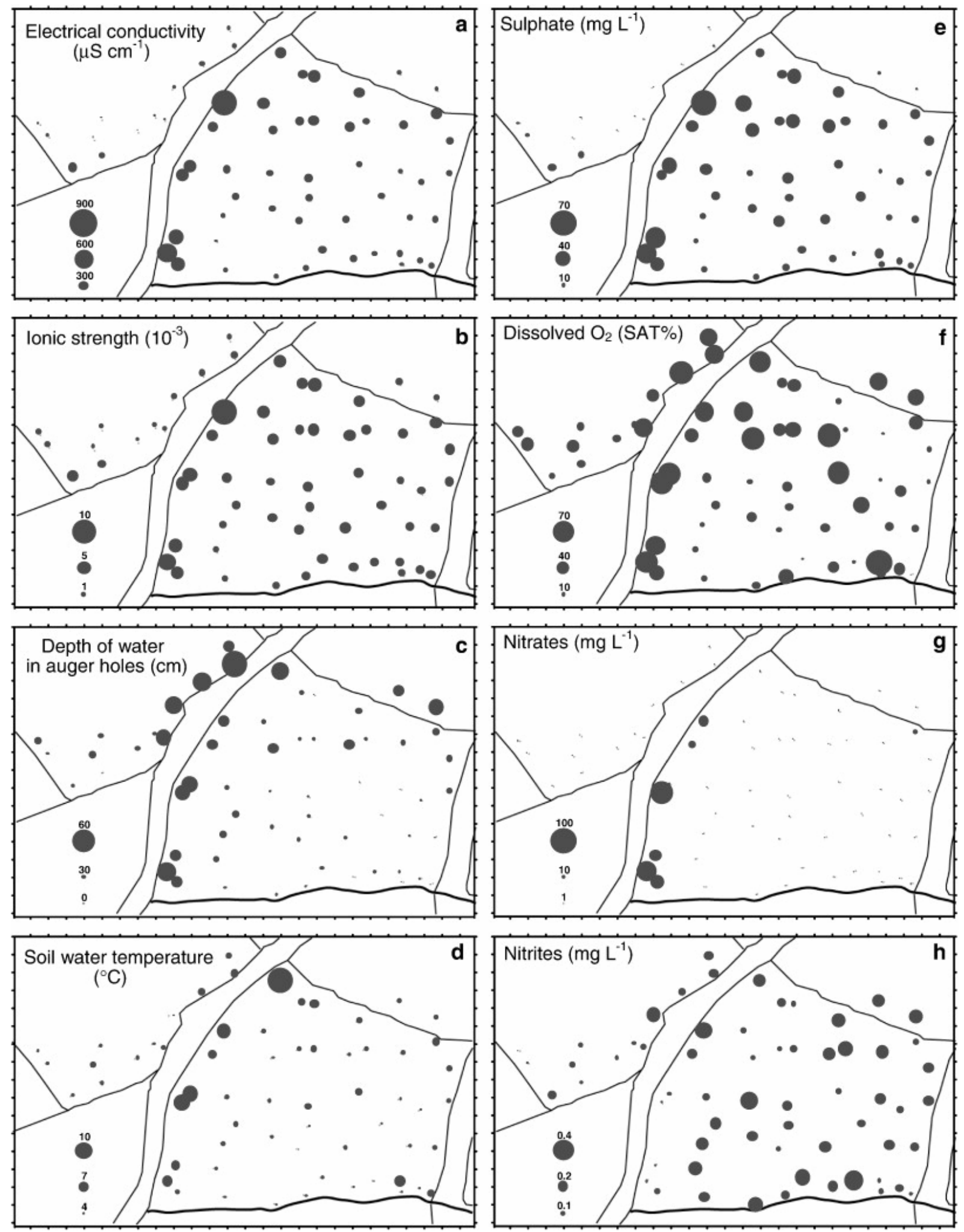

Fig. 2. Soil water depth, electrical conductivity, ionic strength, temperature, $\left[\mathrm{SO}_{4}{ }^{2-}\right]$, dissolved oxygen, $\left[\mathrm{NO}_{3}{ }^{-}\right]$and $\left[\mathrm{NO}_{2}{ }^{-}\right]$, dissolved organic carbon, $\mathrm{pH},\left[\mathrm{Fe}^{2+}\right],\left[\mathrm{Mn}^{2+}\right]$, fluorescence, alkalinity, $\mathrm{Fe}(\mathrm{III})$ and fluoride. 


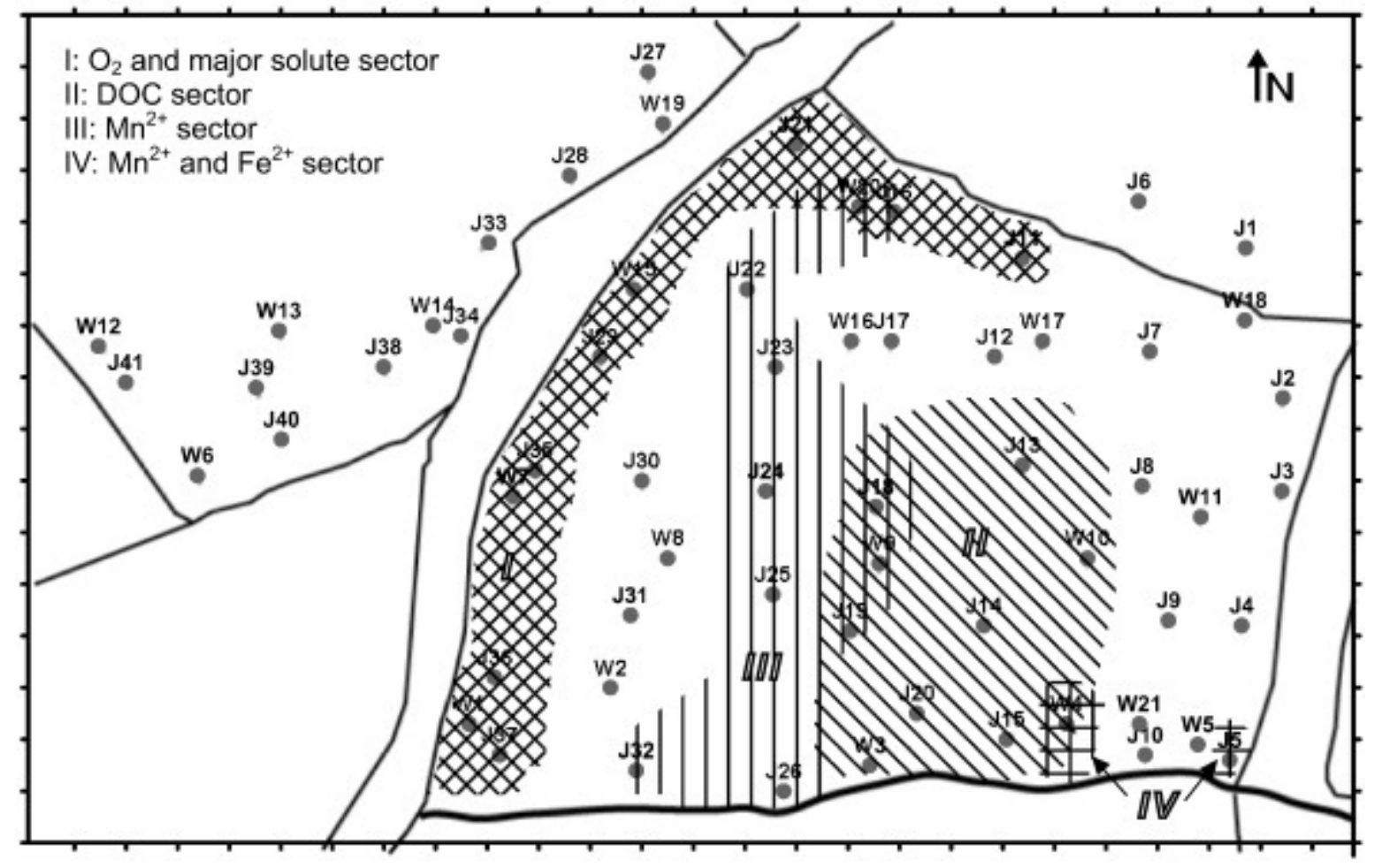

Fig. 3. Map of geochemical sectors identified: (I) mineral salt- and dissolved oxygen-rich sector, (II) DOC-rich sector (III), dissolved $\mathrm{Mn}^{2+}$ rich sector and (IV) $\mathrm{Mn}^{2+}$ and $\mathrm{Fe}^{2+}$ anoxic locations. 